\title{
Phosphorylation of histone H4 Ser1 regulates sporulation in yeast and is conserved in fly and mouse spermatogenesis
}

\author{
Thanuja Krishnamoorthy, ${ }_{1}^{1}$ Xin Chen, ${ }^{2}$ Jerome Govin, ${ }^{3}$ Wang L. Cheung, ${ }^{4,7}$ Jean Dorsey, ${ }^{1}$ \\ Karen Schindler, ${ }^{5}$ Edward Winter, ${ }^{5}$ C. David Allis, ${ }^{4,8}$ Vincent Guacci, ${ }^{6}$ Saadi Khochbin,, \\ Margaret T. Fuller, ${ }^{2}$ and Shelley L. Berger ${ }^{1,9}$ \\ ${ }^{1}$ Gene Expression and Regulation Program, The Wistar Institute, Philadelphia, Pennsylvania 19104, USA; ${ }^{2}$ Department of \\ Developmental Biology, Stanford University School of Medicine, Stanford, California 94305, USA; ${ }^{3}$ Institut National de la \\ Santé et de la Recherche Médicale (INSERM) U309, Institut Albert Bonniot Faculté de Médecine, 38706 La Tronche, France; \\ ${ }^{4}$ Department of Biochemistry and Molecular Genetics, University of Virginia, Charlottesville, Virginia 22908, USA; \\ ${ }^{5}$ Department of Biochemistry and Molecular Biology, Thomas Jefferson University, Philadelphia, Pennsylvania 19107, USA; \\ ${ }^{6}$ Department of Embryology, Howard Hughes Medical Institute/Carnegie Institution, \\ Baltimore, Maryland 21218, USA
}

Sporulation in Saccharomyces cerevisiae is a highly regulated process wherein a diploid cell gives rise to four haploid gametes. In this study we show that histone H4 Ser1 is phosphorylated (H4 S1ph) during sporulation, starting from mid-sporulation and persisting to germination, and is temporally distinct from earlier meiosis-linked H3 S10ph involved in chromosome condensation. A histone H4 S1A substitution mutant forms aberrant spores and has reduced sporulation efficiency. Deletion of sporulation-specific yeast Sps1, a member of the Ste20 family of kinases, nearly abolishes the sporulation-associated H4 S1ph modification. H4 S1ph may promote chromatin compaction, since deletion of SPS1 increases accessibility to antibody immunoprecipitation; furthermore, either deletion of Sps1 or an H4 S1A substitution results in increased DNA volume in nuclei within spores. We find $\mathrm{H} 4 \mathrm{S1} \mathrm{ph}$ present during Drosophila melanogaster and mouse spermatogenesis, and similar to yeast, this modification extends late into sperm differentiation relative to H3 S10ph. Thus, H4 S1ph may be an evolutionarily ancient histone modification to mark the genome for gamete-associated packaging.

[Keywords: Saccharomyces cerevisiae; fly and mouse spermatogenesis; genome compaction; histone H4 phosphorylation; kinase; yeast sporulation]

Received June 8, 2006; revised version accepted July 25, 2006.

Genetic and epigenetic information is transferred to a new cell generation through the gametogenesis process. Dramatic changes in chromatin structure occur during both metazoan spermatogenesis and yeast sporulation involving DNA compaction. In addition, spermatogenesis requires removal of most canonical histones and substitution with histone variants and histone replacement proteins (Govin et al. 2004; Kimmins and SassoneCorsi 2005).

The nucleosome is the fundamental repeating unit of chromatin and harbors an octamer of basic histone proteins (two copies of dimeric $\mathrm{H} 3 / \mathrm{H} 4$ and $\mathrm{H} 2 \mathrm{~A} / \mathrm{H} 2 \mathrm{~B}$ )

Present addresses: ${ }^{7}$ Department of Pathology, Johns Hopkins Hospital, Baltimore, MD 21287, USA; ${ }^{8}$ Laboratory of Chromatin Biology, The Rockefeller University, New York, NY 10021, USA.

${ }^{9}$ Corresponding author.

E-MAIL berger@wistar.org; FAX (215) 898-0663.

Article is online at http://www.genesdev.org/cgi/doi/10.1101/gad.1457006. wrapped by $\sim 147$ base pairs (bp) of DNA (Luger et al. 1997). Nucleosomes pack into higher-order chromatin structures, whose precise architectures are not understood. Post-translational modifications (PTMs) of histones (including acetylation, phosphorylation, methylation, and ubiquitylation) regulate chromatin function and contribute to its folding. PTMs occur in distinct patterns and in diverse cellular pathways. For example, H3 S10ph correlates with both mitotic/meiotic chromosome condensation and transcriptional activation (Nowak and Corces 2004). Chromosome condensation includes a large number of possibly redundant histone phosphorylation marks, including S10 (Hendzel et al. 1997), T3 (Polioudaki et al. 2004), T11 (Preuss et al. 2003), S28 (Goto et al. 1999, 2002) within H3, S1 within H4 (Barber et al. 2004), S1 within H2A (Barber et al. 2004), and S10 in H2B (Ahn et al. 2005b). Phosphorylation at H3 S10 has been causally linked to mitotic 
chromosome condensation in Tetrahymena (Wei et al. 1999).

Yeast sporulation is triggered by nutrient deprivation, including nitrogen starvation, growth in nonfermentable carbon sources, or the absence of glucose (Kupiec et al. 1997). The diploid yeast cell then initiates a transcriptional cascade characterized by expression of several temporally distinct classes of genes: early, middle, midlate, and late (Mitchell 1994; Chu et al. 1998; Primig et al. 2000). DNA is replicated, and two meiotic divisions occur during the early and middle stages of the sporulation program. Mid-late and late gene products regulate spore morphogenesis/maturation (Chu and Herskowitz 1998; Chu et al. 1998). Haploid spores remain quiescent for an indefinite time until favorable conditions initiate germination. Spores have a specialized wall that imposes volume restrictions on the nuclei and serves as a physical barrier against environmental stress.

Covalent histone modifications have been characterized during early and middle stages of yeast sporulation, temporally coincident with gene regulation, with the occurrence of recombination of double-strand breaks, and with meiotic chromosome condensation. Dynamic H3 and $\mathrm{H} 4$ acetylation (H3ac and $\mathrm{H} 4 \mathrm{ac}) /$ deacetylation activates transcription of early and middle genes (Chua and Roeder 1995; Rundlett et al. 1998; Burgess et al. 1999; Choy et al. 2001; Deckert and Struhl 2001). DNA synthesis occurs during $\mathrm{S}$ phase followed by meiosis I and II, which are accompanied by histone phosphorylation (Hsu et al. 2000; Ahn et al. 2005b). S10ph on both H2B and H3 correlates with meiotic chromosome condensation and disappears during meiotic divisions. Histone ubiquitylation (ub) and methylation (me) are involved in meiotic DNA recombination and middle gene expression (Nislow et al. 1997; Robzyk et al. 2000; Hwang et al. 2003; Wood et al. 2003; Sollier et al. 2004; Yamashita et al. 2004). It is not known whether histone PTMs influence late gene transcription, or whether they regulate sporeassociated genome compaction.

Higher eukaryotic spermatogenesis is conceptually similar to yeast sporulation in the requirement for remodeling and compaction of the genome. Spermiogenesis is marked by two post-meiotic events. In the first event, spermatocytes differentiate into round, and then elongated spermatids. The second major event involves PTMs of histones, replacement of histones by histone variants, then by highly basic transition proteins (TPs), and, finally, by protamines (Sassone-Corsi 2002; Govin et al. 2004; Kimmins and Sassone-Corsi 2005). These changes in histone composition promote efficient genome compaction, sperm function, and increased fertility (Oliva and Dixon 1991; Yu et al. 2000; Cho et al. 2001; Zhao et al. 2001; Meistrich et al. 2003; Lewis et al. 2004). For example, the timing of H4ac correlates with compaction and may have a direct mechanistic role through binding of the testes-specific bromodomain protein Brdt (Pivot-Pajot et al. 2003). A large number of phosphorylations occur on the testes-specific histone relatives and replacement proteins, whose molecular mechanisms are not yet elucidated, but may be involved in genome compaction /Oliva and Dixon 1991; Wu et al. 2000; Meetei et al. 2002). Many components of the spermatogenesis program, including certain histone PTMs, show evolutionary conservation from yeast to mammals. However, it is not known whether histone replacement proteins have a role in flies and yeast, and if not, how lower eukaryotes achieve compaction with only canonical histones.

There is a paucity of information about the role of histone covalent modifications in the broad chromatinrestructuring events in gametes. In this study, we describe the occurrence of $\mathrm{H} 4 \mathrm{~S} 1 \mathrm{ph}$ during yeast sporulation, as well as during fly and mouse spermatogenesis. H4 S1ph persists after the disappearance of H3 S10ph during gametogenesis in each organism and in yeast is stably present in mature spores. Our findings suggest an evolutionarily conserved role of $\mathrm{H} 4 \mathrm{~S} 1 \mathrm{ph}$ during chromatin compaction in the later stages of gametogenesis.

\section{Results}

H4 S1ph is observed in sporulating yeast cells and is dependent on Sps1, a middle-sporulation-specific kinase

Histone $\mathrm{H} 3$ phosphorylation occurs during both mitotic and meiotic chromosome condensation (Hsu et al. 2000). Because $\mathrm{H} 4 \mathrm{~S} 1 \mathrm{ph}$ is detected during mitotic chromosome condensation (Barber et al. 2004), we tested whether histone H4 S1 is phosphorylated during sporulation. We used an antibody that specifically recognizes $\mathrm{H} 4 \mathrm{~S} 1 \mathrm{ph}$ (Barber et al. 2004; Cheung et al. 2005). Diploid yeast cells were induced to proceed synchronously through sporulation, and samples were taken at the indicated time points. A strong increase in $\mathrm{H} 4 \mathrm{~S} 1 \mathrm{ph}$ occurs at $\sim 10 \mathrm{~h}$ in sporulation media (Fig. 1A). We found that the timing of this modification varies between 8 and $12 \mathrm{~h}$, depending on the severity of starvation, amount of glucose, and aeration of the media (see below).

The timing of the histone $\mathrm{H} 4$ phosphorylation appears to coincide with the expression of middle genes. SMK1 and SPS1 are Ser/Thr kinases that are expressed in a middle-sporulation-specific fashion and function in parallel pathways to regulate spore wall formation (Friesen et al. 1994; Krisak et al. 1994; Chu and Herskowitz 1998; Iwamoto et al. 2005). To determine whether these kinases are required for $\mathrm{H} 4 \mathrm{~S} 1 \mathrm{ph}$, we tested diploid strains deleted for either SPS1 or SMK1 and carrying plasmidborne Flag-H4. S1ph in Flag-H4 immunoprecipitates is induced in the smk1s strain (Fig. 1B, top panel), but the signal is abolished in the sps1D strain (Fig. 1B, bottom panel). This signal reduction was observed both for Flag$\mathrm{H} 4$ and endogenous $\mathrm{H} 4$ (suggesting that mixed octamers immunoprecipitated with Flag antibody). Thus, sporulation-linked H4 S1ph requires Sps1, a middle-sporulationspecific kinase in the Ste20 family of kinases.

SPS1 encodes a kinase whose transcript levels peak at mid-sporulation and then decrease (Friesen et al. 1994). We compared the onset of H4 S1ph and induction of Sps1 protein during the sporulation program (Fig. 1C). FlagSps 1 expression is induced $\sim 12 \mathrm{~h}$ post-induction in 


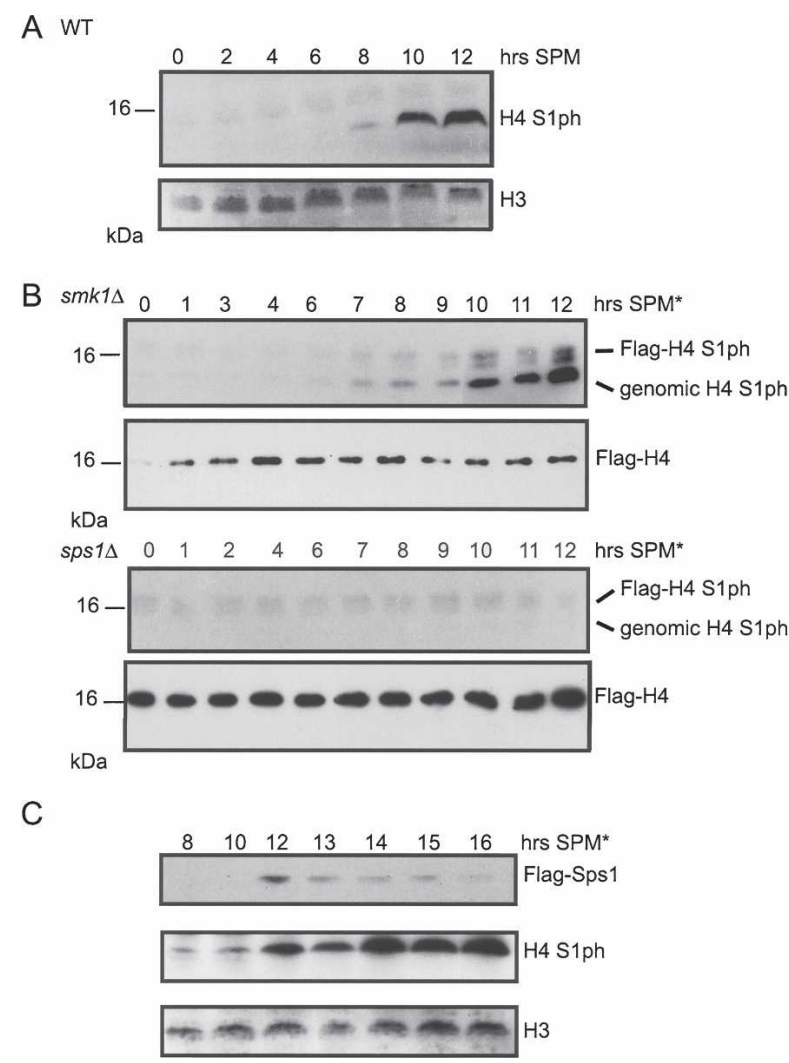

Figure 1. H4 S1ph occurs in sporulation and requires Sps1. (A) Detection of H4 S1ph during sporulation. The wild-type SK1 strain was induced to sporulate, and fractions were collected at the indicated time points. WCEs were prepared, resolved on SDS-PAGE, blotted, and probed either with unmodified H3 (ab1791; Abcam) antibody or with H4 S1ph antibody (Barber et al. 2004). (B) Deletion of Sps1 kinase strongly lowers H4 S1ph, whereas deletion of Smk1 kinase does not affect H4 S1ph.

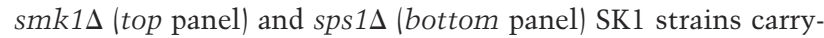
ing Flag-H4 were induced to sporulate, and fractions were collected at the indicated time points. Flag-H4 was immunoprecipitated from WCEs, resolved by SDS-PAGE, blotted, and probed with either Flag-HRP conjugated antibody (Sigma) or H4 S1ph antibody. SPM ${ }^{\star}$ contains $0.05 \%$ glucose. (C) Expression of Flag-Sps1 coincides with appearance of $\mathrm{H} 4 \mathrm{~S} 1 \mathrm{ph}$. WCEs were prepared from the sporulating Flag-Sps1 strain, Western-blotted, and probed with Flag and H4 S1ph antibodies.

sporulation medium containing $0.05 \%$ glucose (where the sporulation program is slightly delayed compared with medium lacking glucose or increased aeration). Induction of $\mathrm{H} 4 \mathrm{~S} 1$ ph exhibits similar timing as epitopetagged Sps1 (Fig. 1C); however, H4 S1ph persists even after Flag-Sps1 has declined (Fig. 1C). Sps1 is degraded rapidly during purification (data not shown); thus we have been unable to determine whether Sps1 is the direct kinase for H4 S1 during sporulation.

\section{Phosphorylation of H3 S10 and H4 S1 are temporally distinct during yeast sporulation}

As mentioned above, H3 S10ph occurs during meiotic chromosome condensation, increasing during late pro- phase and declining as the meiotic divisions occur (Hsu et al. 2000). Because both H3 S10ph and H4 S1ph occur during mitotic chromosome condensation (Barber et al. 2004), it was surprising that S1ph appeared to occur later in sporulation. In fact, $\mathrm{H} 4 \mathrm{~S} 1 \mathrm{ph}$ also occurs in response to DNA damage-induced double-strand breaks in vegetative growth (Cheung et al. 2005; Utley et al. 2005), which are similar to meiosis-specific double-strand breaks that occur in meiotic prophase. These observations led us to further examine the timing of $\mathrm{H} 4 \mathrm{~S} 1 \mathrm{ph}$ induction during sporulation, especially relative to $\mathrm{H} 3 \mathrm{~S} 10 \mathrm{ph}$ and meiotic divisions. Extracts were prepared for Western blotting and, in parallel, cells were DAPI stained to follow the meiotic divisions. The expression of the meiosis-specific Ime2 kinase increases shortly after meiotic induction and increases further as the meiotic divisions are occurring (Fig. 2A, left panel; Benjamin et al. 2003). As previously observed (Hsu et al. 2000), H3 S10ph peaks at 4 h coinciding with early sporulation (Fig. 2A) and then declines by $6 \mathrm{~h}$. In contrast, $\mathrm{H} 4 \mathrm{~S} 1 \mathrm{ph}$ increases at $\sim 8 \mathrm{~h}$, when $80 \%$ of cells have completed either meiosis I or meiosis II (Fig. 2A). Thus, while mitotic chromosome condensation is marked with redundant phosphorylation of $\mathrm{H} 3 \mathrm{~S} 10$ and $\mathrm{H} 4 \mathrm{~S} 1$, these phosphorylations are temporally distinct during sporulation, suggesting separate functions.

We determined the duration of H4 S1ph during sporulation. Western blotting relative to unmodified H3 indicates that it persists to the longest post-meiotic time point tested (30 h) (Fig. 2B). Thus, unlike transient H3 S10ph, H4 S1ph appears to be stable. We examined S1ph during germination, when the haploid gamete begins to grow in nutrient-rich conditions. H4 S1ph declines between 2 and $4 \mathrm{~h}$ following resuspension of the cells in rich YPD medium (Fig. 2B). Thus, $\mathrm{H} 4 \mathrm{~S} 1 \mathrm{ph}$ is a stable modification in spores that is reversed when cells resume mitosis. Induction of $\mathrm{H} 4 \mathrm{~S} 1 \mathrm{ph}$ exhibits similar timing as epitope-tagged Sps1 (Fig. 1C); however, H4 S1ph persists even after Flag-Sps1 has declined (Fig. 1C). Taken together, these data suggest that a H4 S1ph phosphatase is active during germination but not in spores.

\section{Decreased sporulation in histone H4 S1A substitution} mutant

Histone H3 S10ph correlates with mitosis/meiosis; however, substitution mutations in this site do not affect these processes in yeast (Hsu et al. 2000). We investigated the function of $\mathrm{H} 4 \mathrm{~S} 1 \mathrm{ph}$ by generating diploid yeast bearing substitution mutations at Serl within the sole copy of cellular $\mathrm{H} 4$. Cells were collected at the end of the sporulation program, and tetrads were counted under light microscopy to obtain a terminal sporulation frequency. H4 S1A sporulates at approximately one-third of wild-type frequency (Fig. 2C). We found that H4 R3A sporulates with frequency similar to wild type (Fig. 2C), indicating that the effect of S1A mutation is not likely to be caused by nonspecific alteration of the structure of the $\mathrm{H} 4$ tail. 
A
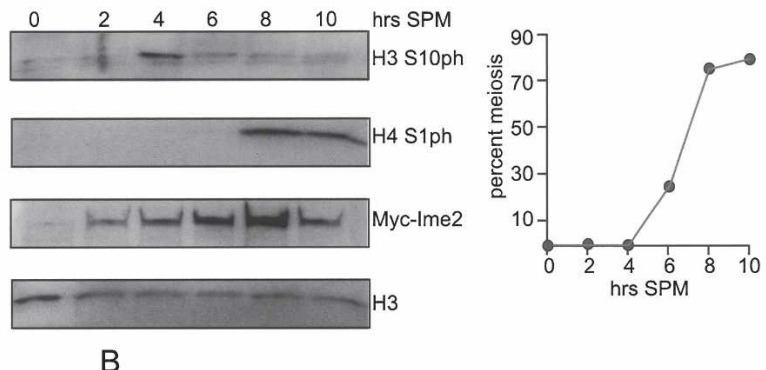

B

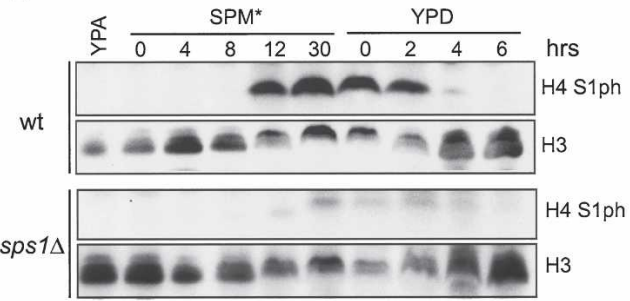

C

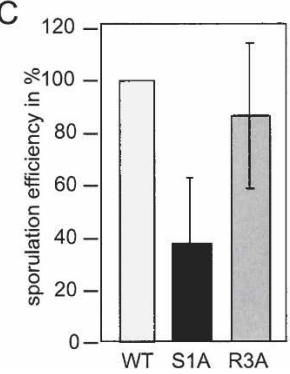

Figure 2. Comparison of $\mathrm{H} 4 \mathrm{~S} 1 \mathrm{ph}$ and $\mathrm{H} 3 \mathrm{~S} 10 \mathrm{ph}$ timing during sporulation. (A) H3 S10ph and $\mathrm{H} 4 \mathrm{~S} 1 \mathrm{ph}$ are temporally distinct. (Left panel) TCA-precipitated extracts prepared from sporulating wild-type SK1 strain carrying Myc-IME2 were resolved on SDS-PAGE gels, blotted, and probed with H3 S10ph (Lo et al. 2000), H4 S1ph, anti-Myc (9E10; Santa Cruz Biotechnologies) or H3 (ab1791; Abcam) antibodies. (Right panel) Cell fractions were also collected from the strain described above and were analyzed for meiotic divisions by counting the number of DAPIstained bodies by immunofluorescence. Cells containing two DAPI-stained bodies were judged to have completed meiosis I, while cells containing four DAPI-stained bodies were judged to have completed meiosis I and II, as depicted in the graph. At 6 $\mathrm{h}$, cells were mostly in meiosis $\mathrm{I}$, while at $8 \mathrm{~h}$, there was a mixture of meiosis I and II. (B) The H4 S1ph mark is stable in mature spores. WCEs were prepared from wild-type and sps1 $1 \Delta$ SK1 strains. The strains were pregrown in acetate media (YPA) prior to sporulation media containing $0.05 \%$ glucose $\left(\mathrm{SPM}^{\star}\right)$. After $\sim 30 \mathrm{~h}$ in $\mathrm{SPM}^{\star}$, cells were allowed to germinate in rich media (YPD). Extracts were probed with $\mathrm{H} 4 \mathrm{~S} 1 \mathrm{ph}$ and $\mathrm{H} 3$ antibodies. (C) H4 S1A mutation reduces sporulation frequency. S288c strains bearing wild-type, S1A, or R3A histone $\mathrm{H} 4$ were maintained in sporulation media $\left(\mathrm{SPM}^{\star}\right)$ for $7 \mathrm{~d}$ to determine terminal sporulation frequency. Cells were observed under a Nikon E600 upright microscope. Tetrads were counted under DIC (100× oil). A total of 716 cells from three different wild-type $\mathrm{H} 4$ colony isolates, 807 cells from two different $\mathrm{H} 4 \mathrm{~S} 1 \mathrm{~A}$, and 465 cells from two different isolates of H4 R3A were counted. These results are representative of more than three independent experiments.

\section{Broad genomic distribution of H4 S1ph and Sps1}

We investigated the localization of $\mathrm{H} 4 \mathrm{~S} 1 \mathrm{ph}$ and Sps1 using quantitative chromatin immunoprecipitation
(ChIP). Fractions were collected from diploid wild-type and $\operatorname{sps} 1 \Delta$ strains after 0 and $10 \mathrm{~h}$ in sporulation media. There was 20- to 30-fold enrichment of H4 S1ph at $10 \mathrm{~h}$ on the promoters of mid-late/late DIT1 and SPS100 genes (Fig. 3A; Percival-Smith and Segall 1986; Law and Segall 1988; Briza et al. 1990; Chu et al. 1998). Consistent with the Western data (Fig. 1B, bottom panel), deletion of SPS1 strongly decreased the H4 S1ph ChIP signal at DIT1 and SPS100 (Fig. 3A, left panel). The H4S1ph ChIP signal that persists in the $\operatorname{sps} 1 \Delta$ strain may either be due to background detection of unmodified histone $\mathrm{H} 4$ or may indicate another kinase pathway to place this modification.

We determined whether $\mathrm{H} 4 \mathrm{~S} 1 \mathrm{ph}$ is specifically enriched at genes expressed at this time, or if it is present more broadly in the genome. We found enrichment at many genomic locations, including the Chr VI-R telomere tip (Fig. 3B, middle panel), the ACT1 and GAL1 genes, as well as the ORF of SPS100 (data not shown). We found by ChIP that endogenously tagged Flag-Sps 1 is present at SPS100, DIT1, and other locations (Fig. 3A, right panel). Thus, both H4 S1ph and Sps1 appear to be broadly distributed across the genome during middle sporulation when H4 S1ph and Sps1 are induced.

We observed by Western analysis that Sps1 expression was transient, whereas $\mathrm{H} 4 \mathrm{~S} 1 \mathrm{ph}$ was persistent through sporulation (Figs. 1C, 2B). We next addressed the persistence of $\mathrm{H} 4 \mathrm{~S} 1 \mathrm{ph}$ and Sps1 genome association by ChIP. The levels peaked at $10 \mathrm{~h}$ in sporulation media and declined thereafter (Fig. 3B). This transience of the ChIP signal is the case both for association at SPS100 (Fig. 3B, left and right panels) and for association at other regions, such as the telomere (Fig. 3B, middle panel). We were surprised that, in the wild-type strain, when assayed by Western blotting, H4 S1ph persists well into germination (Fig. 2B), but when assayed by ChIP, it peaks at $10 \mathrm{~h}$ and declines by $24 \mathrm{~h}$ (Fig. 3B), which is addressed in more detail below.

The broad genomic distribution of H4 S1ph and Sps1 at $10 \mathrm{~h}$ in sporulation media prompted us to test the specificity of the ChIP assay. We examined the localization of Sum1, a repressor of sporulation genes, at its cognate binding sites upstream of SMK1 and DIT1 as well as at the unrelated SPS100 upstream sites. Epitope-tagged Sum 1 is specifically recruited to SMK1 and DIT1 but not to SPS100, while H4 S1ph is again found associated at each of these genes (Fig. 4A), suggesting specificity in the broad codistribution of Sps1 and S1ph.

\section{Sps1 affects histone ChIP accessibility}

To try to reconcile the discrepancy between the Western data (Fig. 2B) and ChIP results (Fig. 3B) with respect to $\mathrm{H} 4 \mathrm{~S} 1 \mathrm{ph}$, we hypothesized that during immunoprecipitation, the $\mathrm{H} 4 \mathrm{~S} 1 \mathrm{ph}$ antibody may not be able to access the target histone because of chromatin compaction occurring at later stages of sporulation. To test this, we carried out ChIP using antibodies recognizing unmodified histones $\mathrm{H} 3$ and $\mathrm{H} 4$, and postulated that the ChIP signals may increase in an sps $1 \Delta$ strain compared with 
Figure 3. H4 S1ph and Sps1 are broadly distributed on the genome. (A, left panel) Enrichment of $\mathrm{H} 4 \mathrm{~S} 1 \mathrm{ph}$ at mid-late and late sporulation genes. ChIP experiments in wild-type SK1 and sps $1 \Delta$ strains at 0 and $10 \mathrm{~h}$ in sporulation medium using an $\mathrm{H} 4 \mathrm{~S} 1 \mathrm{ph}$ antibody. The values obtained at SPS100 and DIT1 promoters were normalized to input and are represented relative to the 0 time point set to 1. (Right panel) General recruitment of Flag-Sps1. In addition to formaldehyde, EGS was also used as a cross-linker for the ChIP experiment. ChIP values obtained at $10 \mathrm{~h}$ into SPM for TATA regions of DIT1 and PHO5, and the telomeric tip region of the right arm of Chromosome VI are presented as the percentage of input. ( $B$, left and middle panels) H4S1ph levels decrease with time by ChIP. ChIP assays using H4 S1ph antibody in wild-type SK1 and sps1D strains at various time points in sporulation medium as shown. The values obtained at the promoter region of SPS100 and telomeric tip region of the right arm of Chromosome VI were calculated as in A. Similar results were obtained using primer pairs that spanned the $5^{\prime}$, middle, and 3' ORF of SPS100. (Right panel) Recruitment of Flag-Sps1 in time course at SPS100. ChIP experiments were carried out in wild-type SK1 and in Flag-Sps1 strains at the indicated time points in SPM. The ChIP experiment was done using formaldehyde alone as the cross-linker but reducing the time of Ip from overnight to $4 \mathrm{~h}$. Values obtained at the SPS100 promoter region were normalized to their respective inputs. The normalized values obtained in Flag-Sps1 were converted to fold over the value obtained in the SK1 strain at the identical time point that was set to 1 .
A

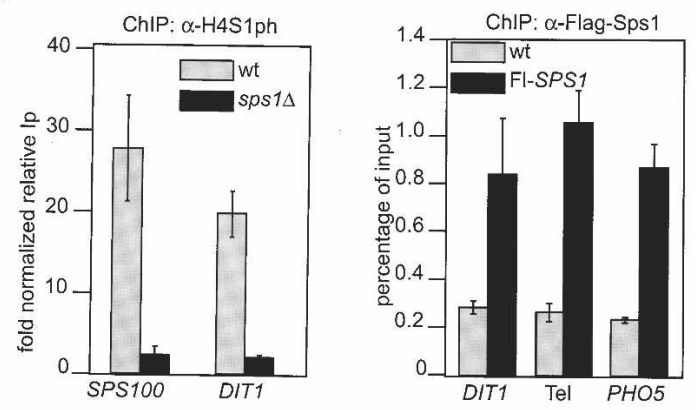

B

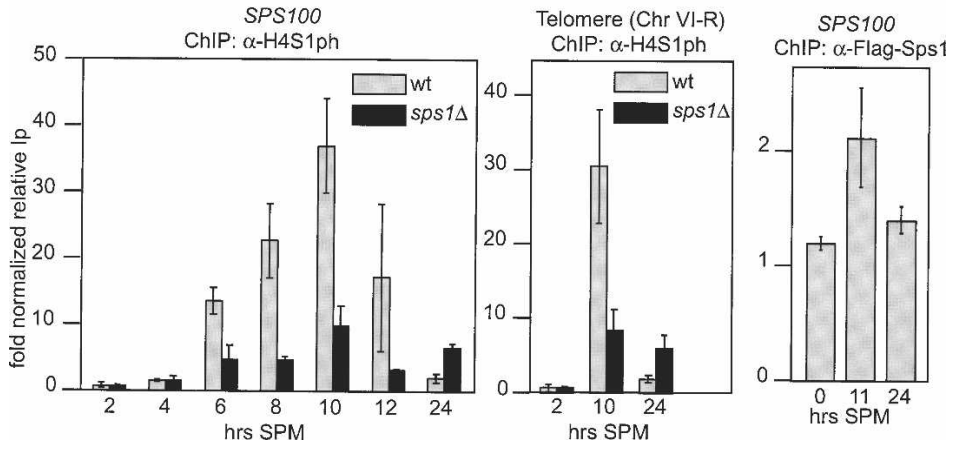

wild type because of potential decompaction in the absence of $\mathrm{H} 4 \mathrm{~S} 1 \mathrm{ph}$. In addition, because H4 S1ph levels are constant in the $s m k 1 \Delta$ strain (Fig. 1B), which has a sporewall-defective phenotype similar to that of the sps1s mutant (Friesen et al. 1994; Krisak et al. 1994), we used this strain as a control for spore formation effects.

At $10 \mathrm{~h}$, both $\mathrm{H} 3$ and $\mathrm{H} 4 \mathrm{ChIP}$ signals are higher in the sps1D strain compared with the wild-type strain (Fig. 4B), and are slightly lower in the smk $1 \Delta$ strain (Fig. 4B, right panel). Beyond $20 \mathrm{~h}$, both the $\mathrm{H} 3$ and $\mathrm{H} 4$ ChIP signals decrease, but to a greater extent in the wild-type and $s m k 1 \Delta$ strains relative to the $s p s 1 \Delta$ strain (Fig. 4B). Note that Western analyses show comparable amounts of histones in each strain across time courses similar to these (relative to total protein) (e.g., Fig. 1). These data suggest that the loss of H4 S1ph ChIP signal at $24 \mathrm{~h}$ in the wildtype strain (Fig. 3B), despite high Western signal (Fig. 2B), may be due to inaccessibility of the histones as a result of chromatin compaction.

\section{DNA volume and nuclear size are increased by mutation of H4 S1A}

To more directly investigate chromatin compaction, and to determine whether compaction is due to H4 S1ph and not to other possible effects caused by deleting SPS1, we measured the area of DAPI-stained nucleus in $\mathrm{H} 4$ wild-type (Fig. 5A, panels a-c,g) compared with H4 S1A (Fig. 5A, panesl d-g) and in $s m k 1 \Delta$ (Fig. 5B, panels a-c,g) compared with sps1s (Fig. 5B, panels d-g) strains. Sporu- lating yeast cells were collected, spheroplasted, and adhered to slides. Images of DAPI-stained cells (Fig. 5A [panels a,d], B [panels a,d]) and the corresponding DIC images (Fig. 5A [panels b,e], B [panels b,e]) were digitally captured, merged (Fig. 5A [panels c,f], B [panels c,f]), and the areas of the spore nuclei were digitally measured (Fig. $5 \mathrm{~A}$ [panel g], B [panel g]). The data were clustered into $0.1-\mu^{2}$ intervals. Larger DAPI-stained nuclei were observed in spores of H4 S1A (mean $=0.96 \pm 0.0498)$ compared with $\mathrm{H} 4$ wild type (mean $=0.7838 \pm 0.032$ ), and in spores of $\operatorname{sps} 1 \Delta($ mean $=0.7682 \pm 0.05)$ compared with smk1s (mean $=0.6458 \pm 0.0259)$ (Fig. 5). The histone substitution strains were treated with proteinase $\mathrm{K}$ and RNase A, which likely accounts for their larger nuclei. Thus, absence of H4 S1ph either in the sps1s strain or in the H4 S1A substitution mutant strain results in increased nuclear volume.

\section{H4 S1ph persists during differentiation of fly spermatids}

We investigated whether $\mathrm{H} 4 \mathrm{~S} 1 \mathrm{ph}$ and $\mathrm{H} 3 \mathrm{~S} 10 \mathrm{ph}$ also occur during male meiosis and spermatogenesis in Drosophila (Fuller 1993). In spermatocytes undergoing the first meiotic division, metaphase I chromosomes stained strongly against both H4 S1ph (Fig. 6A) and H3 S10ph (Fig. 6A') antibodies. The H4 S1ph signal was detected on meiotic chromosomes from prophase through telophase for both meiosis I and meiosis II cells (data not shown). In contrast, H3 S10ph staining was only prominent in metaphase and decreased substantially in anaphase and 
A

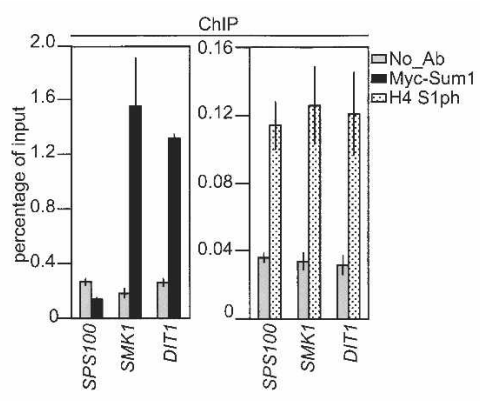

B

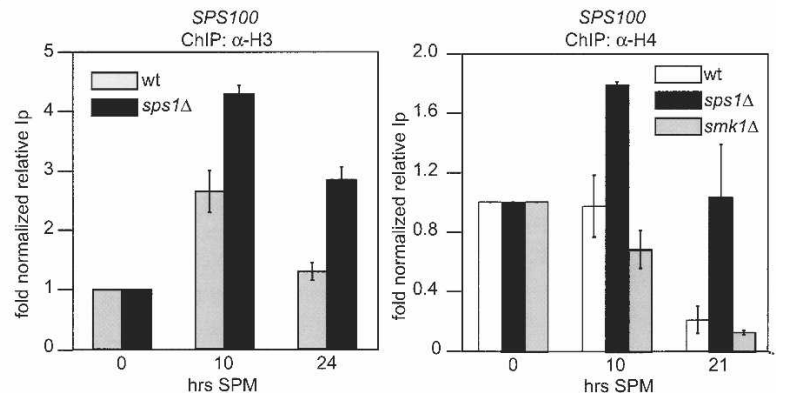

Figure 4. Sps1 promotes genome compaction by phosphorylating histone H4. (A) Specific recruitment of Myc-Sum1. ChIP experiments were carried out in the Myc-Sum1 strain at $10 \mathrm{~h}$ into SPM using an H4 S1ph antibody as well as antibody against the Myc epitope (Santa Cruz Biotechnology, 9E10). Values obtained at the promoter region of SPS100, MSE regions of SMK1, and MSE regions of DIT1 are presented as the percentage of input. (B) Accessibility of histone $\mathrm{H} 3$ and histone H4. ChIP assays used antibodies directed against unmodified histones $\mathrm{H} 3$ and H4 (Abcam, ab10156). Cell fractions were collected from wild-type and sps1D SK1 strains at the indicated time points. Values obtained for SPS100 were calculated as described for Figure 3A.

telophase. The H3 S10ph signal was also not detected in prophase spermatocytes (Fig. 6I, arrowhead). The antibodies did not cross-react between modified $\mathrm{H} 4$ and modified H3 in this assay, as staining of metaphase chromosomes with $\mathrm{H} 4 \mathrm{~S} 1 \mathrm{ph}$ antibody was blocked by competition with $\mathrm{H} 4 \mathrm{~S} 1 \mathrm{ph}$ peptide, but not by unmodified H4 peptide or H3 S10ph peptide (Fig. 6D-F). Likewise, staining of metaphase chromosomes with H3 S10ph antibody was blocked by competition with the cognate peptide, but not by unmodified $\mathrm{H} 3$ peptide or $\mathrm{H} 4 \mathrm{~S} 1 \mathrm{ph}$ peptide (Fig. 6G-I).

Immunofluorescence staining of Drosophila male germ cells undergoing spermatid differentiation revealed certain parallels between differentiation of yeast spores and male gametes in the behavior of $\mathrm{H} 4 \mathrm{~S} 1 \mathrm{ph}$ and $\mathrm{H} 3$ S10ph. During Drosophila spermatogenesis, as in yeast sporulation, H4 S1ph persisted until late in the terminal differentiation stages, while H3 S10ph levels were strongly reduced by the time meiosis was completed. Thus, in round and early elongating haploid spermatids, nuclei stained brightly for H4 S1ph (Fig. 6B), while staining for $\mathrm{H} 3 \mathrm{~S} 10$ ph was nearly undetectable in the same cells (Fig. 6B'). The H4 S1ph epitopes persisted in spermatid nuclei as cells grew flagella and elongated and were still detected in nuclei undergoing chromatin compaction and nuclear shaping (Fig. 6C). Staining with H4 S1ph antibody gradually diminished at the later stages of nuclear elongation and shaping (cf. ${ }^{\star}$ vs. brackets in Fig. $\left.6 \mathrm{C}, \mathrm{C}^{\prime \prime}\right)$ and was not detected in mature spermatids awaiting individualization. Staining for H3 S10ph was not detected in elongating spermatid nuclei at any stage (Fig. $\left.6 \mathrm{C}^{\prime}\right)$. As mentioned above, incubation with competing peptides confirmed that the staining in round and elongating spermatid nuclei was due to H4 S1ph (Fig. 6J-M').

\section{H4 S1ph is present in post-meiotic stages of mammalian spermatogenesis}

We monitored histone H4 S1ph during mammalian spermatogenesis (Sassone-Corsi 2002). Dissociated mouse cells undergoing spermatogenesis were fractionated using a BSA gradient. Extracts from pooled fractions enriched in spermatocytes, round spermatids, and round elongating spermatids were obtained to examine $\mathrm{H} 4$ S1ph and H3 S10ph by immunofluorescence and Western blotting. Consistent with our observations in flies, we detected H4 S1ph by immunofluorescence in spermatocytes and in further differentiated round spermatids, whereas H3 S10ph was observed only in spermatocytes (Fig. 7A, panels a-1). Again, in agreement with the fly data, H4 S1ph disappears in elongating spermatids (Fig. 7A, panel c).

Western blot analysis was carried out on extracts prepared from the different cell types and probed with $\mathrm{H} 4$ S1ph and H3 S10ph antibodies (Fig. 7B). Again, H3 S10ph dramatically decreases after meiosis, while H4 S1ph persists in post-meiotic stages (Fig. 7B). The quality of the fractionation procedure is shown by the pattern of $\mathrm{H} 3$ S10ph specifically in cells containing condensed meiotic chromosomes (Fig. 7, cf A [panels g-i] and 7B). As an additional control, the same blot was probed with an antibody that detects transition protein 2 (TP2), and as expected, TP2 accumulated in elongating cells (Fig. 7B). Interestingly, the pattern of TP2 accumulation appeared to correlate with reduction of $\mathrm{H} 4 \mathrm{~S} 1 \mathrm{ph}$ (Fig. 7B, cf. lanes 5 and 6).

\section{Discussion}

Histones and histone replacement proteins have long been known to be phosphorylated during vertebrate spermatogenesis (Sung and Dixon 1970). Indeed, H4 S1 phosphorylation was discovered in 1970 (Sung and Dixon 1970); however, the significance of this phosphorylation during gametogenesis has been unclear. In this study, we examined S1ph in $\mathrm{H} 4$ during gametogenesis and found that the mark is conserved through evolution, appearing in diverse eukaryotes ranging from yeast to the metazoans Drosophila and mouse. In these three organisms, H4 S1ph persists relatively late in the process of gametogenesis compared with meiosis-correlated H3 S10ph. We find that $\mathrm{H} 4 \mathrm{~S} 1 \mathrm{ph}$ is induced in yeast nearing completion of meiotic divisions, high levels are maintained to the 
A

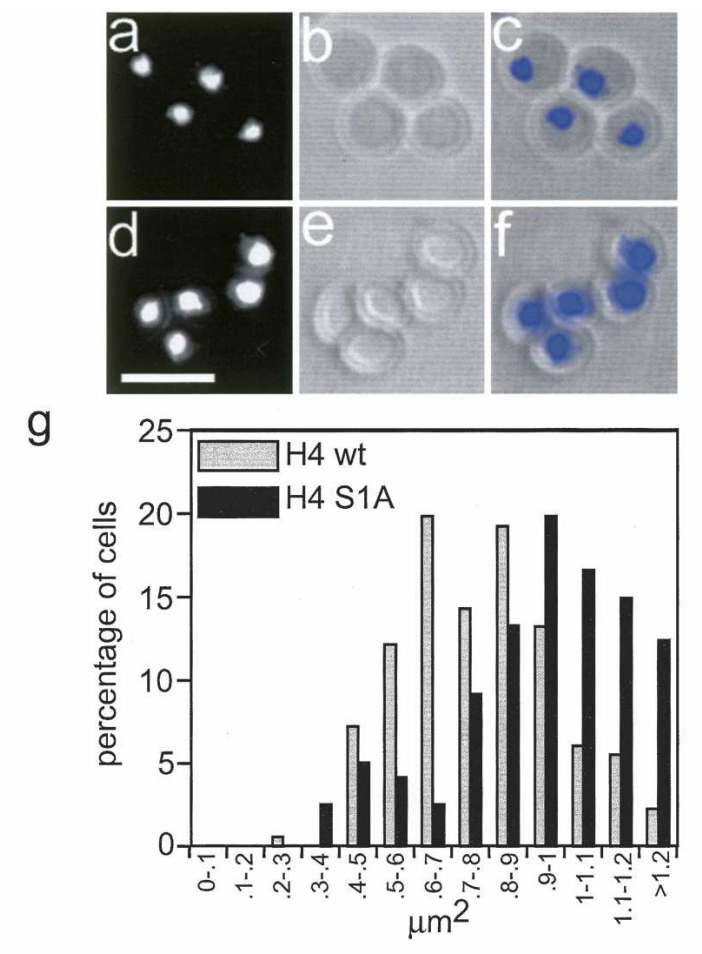

B

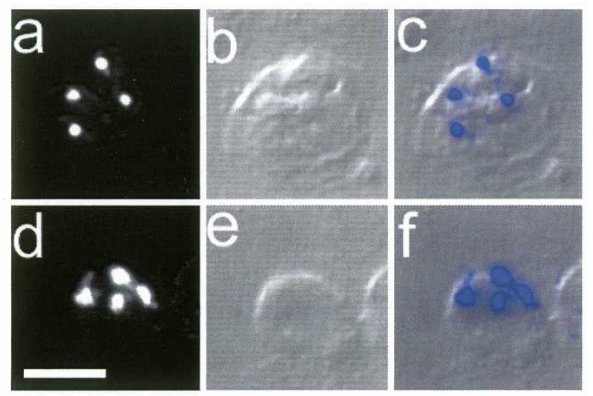

g

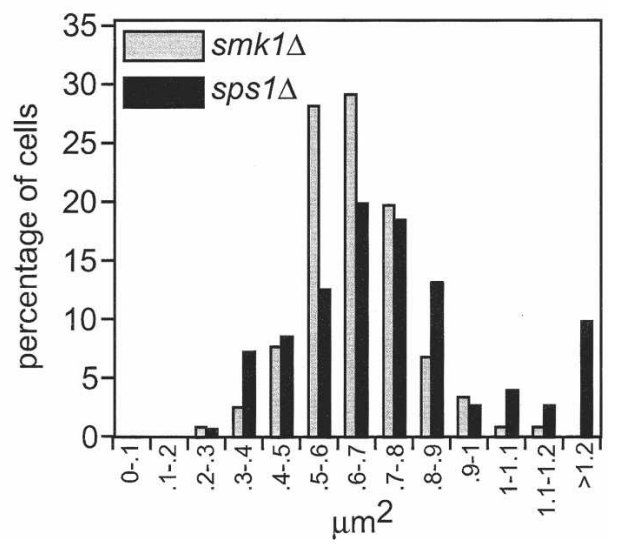

Figure 5. Absence of S1 phosphorylation results in increased nuclear volume. $(A)$ Larger nuclei in H4 S1A strain. Cells from H4 wild-type (panels $a-c$ ) and H4 S1A (panels $d-f$ ) strains at day 5 in SPM were spheroplasted, adhered to slides, treated with Proteinase $\mathrm{K}$ and RNase A, and stained with DAPI. Images were collected using an Olympus upright microscope, and the area of the DAPI-stained spore nuclei was measured using the Image Pro software (shown in panel $g$ ). The DAPI images (panels $a, d$ ) and the corresponding DIC images (panels $b, e$ ) were captured under 100× with oil and merged (panels $c, f$ ). In the case of H4 wild type, 182 spore nuclei were measured, while 121 spore nuclei were measured in the H4 S1A strain. The measurements were certified as statistically significant with a mean of $0.7838394 \pm 0.0323454$ for $\mathrm{H} 4$ wild type and $0.9604283 \pm 0.0497988$ for H4 S1A. Care was taken to limit the quenching of the fluorescence. The measurements were clustered into $0.1-\mu \mathrm{m}^{2}$ intervals and are presented against the percentage of cells $(\mathrm{shown}$

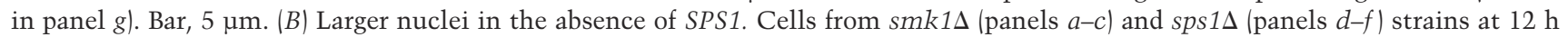
in SPM were collected, spheroplasted, adhered to the slides, and stained with DAPI. Images were collected using an E600 Nikon upright microscope, and the spore nuclei were measured as above. Panels $a$ and $d$ represent the DAPI images and panels $b$ and $e$ represent the corresponding DIC images, while panels $c$ and $f$ are the merged images of DAPI and DIC. The numbers of spore nuclei

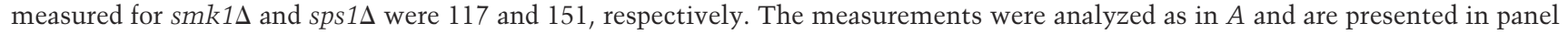
g. Bar, $5 \mu \mathrm{m}$. Nuclei in the $\mathrm{H} 4$ wild-type and H4 S1A strains appear relatively larger (see $A$ ) than in the $\operatorname{smk} 1 \Delta$ and $\operatorname{sps} 1 \Delta$ strains due to proteinase $\mathrm{K}$ treatment.

end of sporulation, and the mark is strongly reduced following resumption of growth. We find that a single substitution mutation of H4 S1A lowers sporulation efficiency compared with wild type and increases the size of the nucleus. Thus, this histone mark appears to have a significant role during sporulation.

We do not yet know whether Sps1 is the direct kinase that phosphorylates $\mathrm{H} 4 \mathrm{~S} 1$ because we cannot detect in vitro activity of recombinant Sps1 prepared in bacteria, and we have been unable to prepare Sps1 from sporulating yeast (T. Krishnamoorthy, unpubl.), which may be due to assembling spore walls (Lynn and Magee 1970) and abundant proteases (Klar and Halvorson 1975) present in sporulating cells. However, Sps1 is required for $\mathrm{H} 4$ S1ph during sporulation (Fig. 1B). Sps1 and H4 S1ph are induced coincidently during mid-sporulation and become chromatin-associated, comparable in both timing and broad locations (Figs. 1C, 3). Deletion of SPS1 or substitution of Serl results in an increased volume of
DNA and increased nuclear size (Fig. 5). Interestingly, Sps1 is a member of the Ste20/p21-activated kinase family, and yeast Ste20 and its mammalian counterpart, Mst1, have been identified as histone (H2B) kinases during apoptosis (Cheung et al. 2003; Ahn et al. 2005a).

\section{H4 S1ph in yeast may be involved in chromatin compaction}

H3 S10ph correlates with mitotic and meiotic chromosome condensation in all eukaryotes examined (Gurley et al. 1973; Paulson and Taylor 1982; Hendzel et al. 1997; Cobb et al. 1999; Hsu et al. 2000). However, it is unclear whether H3 S10ph contributes directly to condensation in yeast, because substitution mutation of the site does not alter either mitosis or meiosis (Hsu et al. 2000). Indeed, many histone phosphorylation sites in addition to H3 S10 are detected during mitosis (Goto et al. 1999, 2002; Preuss et al. 2003; Barber et al. 2004; Polioudaki et 

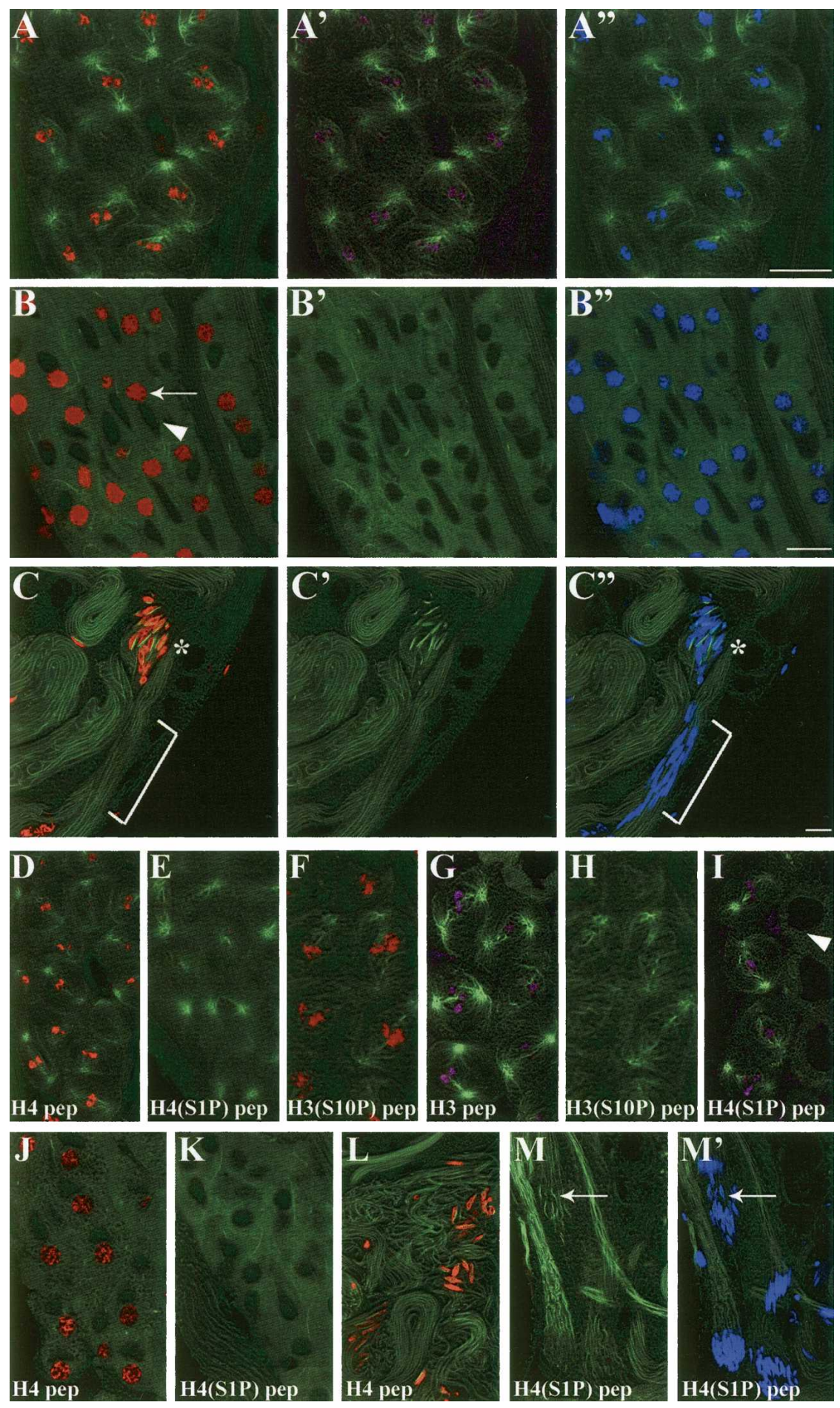

Figure 6. $\mathrm{H} 4 \mathrm{~S} 1 \mathrm{ph}$ in Drosophila spermatogenesis. Immunofluorescence images of Drosophila male germ cells undergoing meiosis and spermatid differentiation stained with H4 S1ph (red) and/or H3 S10ph (purple) antibodies. For all images, flies carried an $\alpha$-tubulin-GFP transgene expressed under control of a ubiquitin promoter, allowing different stages of meiotic division and spermatid differentiation to be distinguished based on characteristic cytoskeletal structures: (green) $\alpha$-tubulin. $A^{\prime \prime}, B^{\prime \prime}, C^{\prime \prime}$, and $M^{\prime}$ show corresponding image stained with DAPI (blue) to highlight DNA. $\left(A-C^{\prime}\right)$ Samples costained with $\mathrm{H} 4$ S1ph $(A, B, C)$ and H3 S10ph $\left(A^{\prime}, B^{\prime}, C^{\prime}\right)$ antibodies. Bar, $10 \mu \mathrm{m}$. $\left(A-A^{\prime \prime}\right)$ Metaphase of meiosis I. $\left(B-B^{\prime \prime}\right)$ Early haploid spermatids initiating the first steps of cell elongation. (Arrow) Spermatid nucleus. (Arrowhead) Mitochondrial derivative initiating elongation. $\left(C-C^{\prime \prime}\right)$ Late-stage spermatids with elongated flagella. $\left({ }^{\star}\right)$ A cluster of spermatid nuclei part way through nuclear shaping. Note array of microtubules (bright green) along one side of each nucleus characteristic of this stage. (Bracket) A cluster of nuclei from more mature spermatid cysts is shown, lacking the perinuclear microtubule array along one side of the nucleus. $(D-M)$ Peptide competition assays. $(D-F)$ Cells in meiotic metaphase II $(D, E)$ or I $(F)$ stained with $\mathrm{H} 4 \mathrm{~S}$ 1ph competed with unmodified $\mathrm{H} 4$ peptide $(D), \mathrm{H} 4$ S1ph peptide $(E)$, and H3 S10ph peptide $(F)$. $(G-I)$ Cells in metaphase I stained with $\mathrm{H} 3$ S10ph antibody competed with unmodified $\mathrm{H} 3$ peptide $(G), \mathrm{H} 3 \mathrm{~S}$ 10ph peptide $(H)$, and H4 S1ph peptide $(I)$. $\left(J-M^{\prime}\right)$ Differentiating spermatids stained with $\mathrm{H} 4 \mathrm{~S} 1 \mathrm{ph}$ antibody. $(J, K)$ Round spermatids competed with unmodified $\mathrm{H} 4$ peptide $(J)$ and H4 S1ph peptide (K). $\left(L-M^{\prime}\right)$ Late-stage elongated spermatids competed with unmodified $\mathrm{H} 4$ peptide (shown in $L) .\left(M, M^{\prime}\right)$ H4 S1ph peptide. $M^{\prime}$ shows $\alpha$-tubulin and DAPI signal corresponding to image in $M$. (Arrow) Cluster of spermatid nuclei in mid-elongation that still retain the perinuclear microtubule array along one side. al. 2004), but none of these, or combinations of these, have yet been shown to alter growth in yeast (Hsu et al. 2000; W.S. Lo and S.L. Berger, unpubl.). In contrast, our results show reduction of overall sporulation efficiency by single substitution mutation of the H4 S1 site (Fig. 2C).

Our data suggest that S1ph plays a role in genome compaction. $\mathrm{H} 4 \mathrm{~S} 1 \mathrm{ph}$ is persistent in spores and is strongly reduced between 2 and $4 \mathrm{~h}$ post-germination (Fig. 2B). Consistent with a possible role in broad genome compaction, we detect the mark at many genomic locations throughout the genome (Figs. 3, 4A). Deletion of Sps1 was previously shown to alter transcription of mid-late and late sporulation genes (Friesen et al. 1994). However, because we find both the H4 S1ph mark and the putative kinase Sps1 at many genomic positions by 


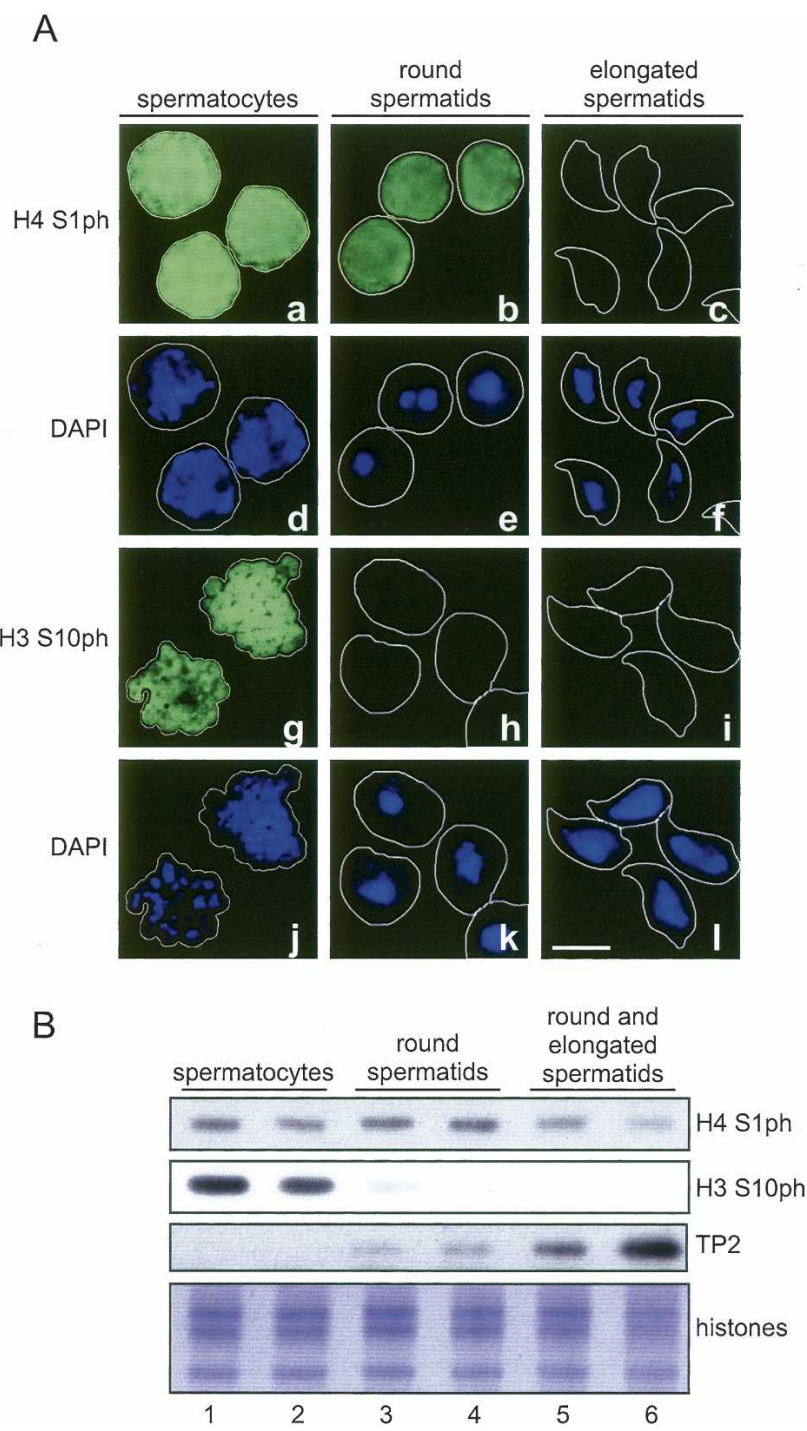

Figure 7. H4 S1ph during mouse spermatogenesis. (A) Immunofluorescence of mouse germ cells undergoing spermatogenesis. Spermatocytes and round and elongated spermatids were either DAPI stained or stained with $\mathrm{H} 4 \mathrm{~S} 1 \mathrm{ph}$ or H3 S10ph antibodies. Bar, $5 \mu \mathrm{m}$. (B) Western analysis of differentiated mouse germ cell fractions. Protein extracts prepared from various cell fractions as shown in the figure were resolved on SDS-PAGE and Western-blotted. The blots were probed with anti H4 S1ph, H3 S10ph, and TP2 antibodies. The histones were Coomassie blue stained.

ChIP, and not specifically at mid-late and late sporulation genes, it appears that the role of $\mathrm{H} 4 \mathrm{~S} 1 \mathrm{ph}$ is unlikely to be solely related to induction of these sets of genes. Most directly implicating a role for $\mathrm{H} 4 \mathrm{~S} 1 \mathrm{ph}$ in DNA compaction, we observe an increase in the size of the nucleus both in the absence of Sps1 as well as in the H4 S1A substitution mutant (Fig. 5).

$\mathrm{H} 4 \mathrm{~S} 1 \mathrm{ph}$ may have a direct role in chromatin compaction within yeast spores. The $\mathrm{N}$-terminal tails of histones are involved in chromatin fiber folding (Moore and Ausio 1997; Carruthers and Hansen 2000), and the X-ray crystal structure of the yeast mononucleosome reveals crystal packing contacts between the $\mathrm{H} 4$ tail and the DNA of a neighboring particle, suggesting a possible role in internucleosome contact in vivo (Suto et al. 2000; Zheng and Hayes 2003). In vitro biochemical analysis indicates that amino acids $14-19$ of the H4 N-terminal tail, and not tails of the other three core histones, are critical for chromatin folding (Dorigo et al. 2003), and H4 K16ac inhibits the formation of higher-order chromatin structures (Shogren-Knaak et al. 2006). H4 S1ph may oppose H4 K16 acetylation (Utley et al. 2005).

\section{In metazoans, H4 S1ph persists beyond the end of meiosis}

Similarities in the processes of sporulation and spermatogenesis, particularly in the drastic reduction in nuclear volume in both processes, led us to examine whether H4 S1ph might also correlate with the timing of chromatin compaction during the latter process. We detect H4 S1ph extending well beyond the time that meiosis-associated H3 S10ph is reduced during Drosophila and mouse spermatogenesis (Figs. 6, 7). In these metazoans, H3 S10ph and H4 S1ph both occur during meiotic divisions and thus may play a role in chromosome condensation. However, following meiotic divisions, the $\mathrm{H} 3$ S10ph is dramatically lowered, while H4 S1ph persists during the early stages of the developing spermatids when the genome begins to be compacted (Fuller 1993). This is true in mouse, as $\mathrm{H} 4 \mathrm{Slph}$ continues to be present beyond the meiotic divisions and begins to be reduced contemporaneously with replacement of histones by the highly basic transition proteins (Fig. 7B). Although we do not yet know whether $\mathrm{H} 4 \mathrm{~S} 1$ ph has a role in genome compaction in metazoans, our data indicate that $\mathrm{H} 4 \mathrm{~S} 1 \mathrm{ph}$ has an additional role beyond meiotic divisions, as is the case in yeast. One clear difference between H4 S1ph in lower eukaryotes compared with metazoans is the persistence of the mark in mature spores and elimination only after germination. Thus, while H4 S1ph may directly promote stable chromatin compaction in mature spores, its role in metazoans may help to compact the genome connected to histone replacement by basic transition proteins (Govin et al. 2004).

While many histone modifications have been correlated with broad genomic mechanisms such as transcription and DNA repair, the role of only a few modifications has been elucidated in higher-level biological processes. Here we report that a central biological process, gametogenesis, is critically controlled in yeast by a single histone modification. The similarities we observe between yeast and metazoans in the persistence of $\mathrm{H} 4 \mathrm{~S} 1 \mathrm{ph}$ after the decline of H3 S10ph emphasizes its importance.

\section{Materials and methods}

Plasmids and yeast strains

Site-directed mutagenesis was used to generate histone $\mathrm{H} 4 \mathrm{mu}-$ tations in plasmid pRM204 (HHF2-HHT2 CEN-ARS1 TRP). 
Plasmids pTK54 (hhf2 S1A-HHT2 CEN-ARS1 TRP) and pTK59 (hhf2 R3A-HHT2 CEN-ARS1 TRP) were plasmid-shuffled into

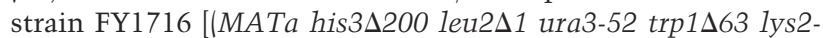
128d) (hht1-hhf1) $\Delta::$ LEU2 (hht2-hhf2) $\Delta::$ HIS3 pDM9(HHT1HHF1 CEN-ARS1 URA3)] to yield strains TY97 and TY98, respectively. Yeast strain ySL151, isogenic to FY1716 but carrying pRM204 instead of pDM9, was used as the wild-type control for histone H4. All the above strains were transformed with a yCP50 plasmid containing $H O$ to switch the mating type and promote mating to give rise to diploids. The $H O$ plasmid was later evicted, and the diploid strains thus generated were TY128 (wt H4), TY129 (H4 S1A), and TY130 (H4 R3A). These strains were used for assaying sporulation frequency.

To study H4 S1ph by Western analysis and ChIP, the following strains with an SK1 background were used. Diploid wildtype SK1 (LNY150: MATa/ 1 leu2:: hisG/leu2:: hisG trp1:: hisG/ trp1::hisG lys2-SK1/lys2-SK1 his4-N/his4-G ura3-SK1/ura3SK1 ho::LYS2/ho::LYS2); sps1s strain (MDPY6, genotype identical to LNY150 except having an additional disruption,

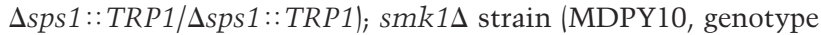
identical to LNY150 except having an additional disruption, $\Delta s m k 1:: L E U 2 / \Delta s m k 1:: L E U 2)$, Myc-Sum1 (DBY36, genotype identical to LNY150 except having NDT80-HA:URA3/NDT80HA:URA3 SUM1-MYC:TRP1/SUM1-MYC:TRP1), and FL-SPS1/ TY156 strain. The diploid TY156 strain carrying FL-SPS1 was created by first $\mathrm{C}$-terminal-Flag $(2 \times)$ tagging the chromosomal SPS1 in a haploid strain with SK1 background by using a TRP marker and following the method as described (Longtine et al. 1998), and the tagging was checked by standard procedures. The haploid Flag-SPS1 strain was thereafter transformed with a $\mathrm{HO}$ plasmid as described above to make diploids. Plasmid pF31 (FI-

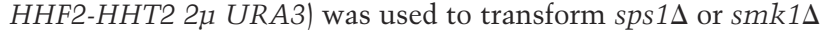
for Flag immunoprecipitations of histone H4. For monitoring expression of Myc-Ime2, strain KSY187 (MATa/ $\alpha$ IME213XMYC::TRP1/IME2-13XMYC::TRP1 ura3/ura3 leu2:: hisG/ leu2::hisG trp1- $\Delta F A::$ hisG/trp1- $\Delta F A::$ hisG lys2/lys2 ho::hisG/ ho::hisG his3-11, 15/his3-11, 15) (Benjamin et al. 2003) was used.

\section{Culture conditions}

A single colony from a fresh plate was used to inoculate $5 \mathrm{~mL}$ of YPD/selective SC media for an overnight growth at $30^{\circ} \mathrm{C}$. The cells of the overnight culture were harvested, washed with water, and used to inoculate $50 \mathrm{~mL}$ of YPA at $0.02 \mathrm{OD}_{600 \mathrm{~nm}}$ and allowed to grow to $0.5 \mathrm{OD}_{600 \mathrm{~nm}}$ at $30^{\circ} \mathrm{C}$. The YPA culture was scaled up to the experimental requirements, and cells were harvested, washed, and finally used to inoculate SPM without glucose (SPM) or with $0.05 \%$ glucose $\left(\mathrm{SPM}^{\star}\right)$ at $2.0 \mathrm{OD}_{600 \mathrm{~nm}}$ at $30^{\circ} \mathrm{C}$. Aliquots of sporulating cells were taken at various intervals either for preparing whole-cell extracts (WCEs) or for ChIP.

\section{DAPI staining}

Cells equivalent to $1 \mathrm{OD}_{600 \mathrm{~nm}}$ were harvested and resuspended in $1 \mathrm{~mL}$ of $90 \%$ ethanol and incubated with $1 \mu \mathrm{L}$ of $10 \mathrm{mg} / \mathrm{mL}$ of 4',6-diamidino-2-phenylindole (DAPI) stain (Sigma) in the dark for $10 \mathrm{~min}$. The cells were washed three times with $1 \mathrm{~mL}$ of $\mathrm{H}_{2} \mathrm{O}$ and resuspended in $50-100 \mu \mathrm{L}$ of $\mathrm{H}_{2} \mathrm{O}$. Five microliters of the cell suspension was placed on a glass slide to observe the cells. This method was used for monitoring the frequency of sporulation. In the case of measuring the DAPI-stained nuclei, the following procedure was used. Yeast cells were processed as described (Guacci et al. 1994) with the following modifications. Sporulating yeast cells were diluted to $0.5 \mathrm{OD}_{600 \mathrm{~nm}}$ and fixed with formaldehyde. The extent of spheroplasting was deter- mined by monitoring the cells under the microscope. The concentration of proteinase $\mathrm{K}$ was $10 \mu \mathrm{g} / \mathrm{mL}$. The cells were stained with DAPI, and the images were captured using a fluorescent upright microscope.

\section{Yeast WCE preparation}

Yeast cells were harvested by spinning down cultures at $\sim 3000$ rpm for $3 \mathrm{~min}$ at $4^{\circ} \mathrm{C}$. The cells were washed with ice-cold water once and broken in lysis buffer $(50 \mathrm{mM}$ Tris- $\mathrm{HCl}$ at $\mathrm{pH} 7.4 ; 150$ $\mathrm{mM} \mathrm{NaCl} ; 0.1 \%$ NP-40; $5 \mathrm{mM} \mathrm{MgCl}{ }_{2} ; 10 \mathrm{mM} \mathrm{NaF} ; 50 \mathrm{mM}$ $\beta$-glycerophosphate; protease inhibitors that included pepstatin, leupeptin, aprotinin, protease inhibitor tablets from Roche and $1 \mathrm{mM}$ PMSF; phosphatase inhibitor cocktail from Sigma) using glass beads and the bead beater (Bio-Spec). The lysate was spun at $14,000 \mathrm{rpm}$ at $4^{\circ} \mathrm{C}$ for $15 \mathrm{~min}$, and the supernatant/WCE was collected and stored at $-80^{\circ} \mathrm{C}$. Protein estimation was done using the Bradford protein estimation kit.

\section{Flag immunoprecipitation}

Fifty microliters of $50 \%$ slurry of Flag M2 agarose resin (Sigma) equilibrated in lysis buffer was used for immunoprecipitation from $1 \mathrm{mg}$ of WCE. The binding reactions were incubated overnight at $4^{\circ} \mathrm{C}$ on a roller and washed four times with $1 \mathrm{~mL}$ of lysis buffer; bound proteins were extracted with $30 \mu \mathrm{L}$ of $2 \times$ sample buffer and heated, and an aliquot was used for checking the expression of Flag fusion proteins. Samples were resolved on $10 \%-20 \%$ SDS-PAGE gel and transferred to a nitrocellulose membrane and probed with the antibody.

\section{ChIP}

Fifty-milliliter aliquots of the sporulating cells were collected at various time points, cross-linked with formaldehyde, and processed for ChIP as described (Henry et al. 2003). For Flag-Sps1 ChIP, cells were first cross-linked with 1.5 mM EGS (100 mM stock prepared in DMSO) for 25 min before cross-linking with formaldehyde for $15 \mathrm{~min}$. The antibodies used for ChIP were $\alpha$-H4S1ph, $\alpha$-Flag (M2; Sigma), and H3 (ab1791; Abcam). Primer pairs spanning the TATA regions of SPS100, DIT1, and PHO5; MSE regions of $S M K 1$ and DIT1; and the Telomeric Tip regions of the right arm of Chromosome VI were used to amplify the inputs and eluates obtained by ChIP in a Thermal Cycler (ABI Prism 7000 from Applied Biosystems). Each amplification was done in duplicate, and the average signal from the eluate was divided by its average input signal for normalizations. The sequence of the primer pairs will be provided on request.

\section{Immunofluorescence on fly testes}

Drosophila testes from flies carrying a $\mathrm{P}\left[\mathrm{w}^{+}\right.$, Ubi-Tubulin $]$ transgene (obtained from C. Gonzales, Barcelona, Spain) were stained for immunofluorescence as in Hime et al. (1996) and Yamashita et al. (2003). Testes were dissected in $1 \times$ PBS and transferred to a siliconized slide; the slide was then frozen in liquid nitrogen, and the coverslip was removed with a razorblade. Samples were then incubated at $-20^{\circ} \mathrm{C}$ in $100 \%$ ethanol for $10 \mathrm{~min}$; fixed in $4 \%$ formaldehyde (in 1× PBS buffer) for 7 min at room temperature; permeabilized by two rounds of incubation in $1 \times$ PBS, $0.3 \%$ Triton $\mathrm{X}-100$, and $0.3 \%$ sodium deoxycholate for 15 min each; rinsed with $1 \times$ PBST (PBS, $0.1 \%$ Triton X-100) for $10 \mathrm{~min}$; then incubated in primary antibody in $1 \times$ PBS and $3 \%$ BSA overnight at $4{ }^{\circ} \mathrm{C}$. $\mathrm{H} 4 \mathrm{~S} 1 \mathrm{ph}$ antibody was used at 1:2000 dilution. H3 S10ph antibody (Upstate Biotechnology \#RR002) was used at 1:100 dilution. Samples were rinsed 
three times in $1 \times$ PBST ( $1 \times$ PBS, $0.1 \%$ Triton X-100), then incubated for $2 \mathrm{~h}$ at room temperature in Alexa fluor-conjugated anti-rabbit and anti-mouse secondary antibodies diluted in $1 \times$ PBS and $3 \%$ BSA to concentrations recommended by the manufacturer (Molecular Probes, Inc.). Samples were rinsed three times in $1 \times$ PBST, then mounted in VECTORSHIELD medium with DAPI staining (Vector Lab, Inc. \#H-1200). For peptide competition assays, each primary antibody was incubated with the designated peptide at a final concentration of $10 \mu \mathrm{g} / \mathrm{mL}$ peptide at room temperature for $4 \mathrm{~h}$ prior to application to the sample. Images were taken on a Leica TCS SP2 AOBS confocal light microscope and processed in Adobe Photoshop.

\section{Mouse spermatogenic cell fractionation and Western analysis}

Spermatogenic cells were fractioned according to the Bellvé method (Bellve 1993). A detailed protocol has been published recently (Pivot-Pajot et al. 2003). Briefly, testes were dissected and processed to obtain a homogeneous cell suspension. The cell suspension was laid on the top of a $2 \%-4 \%$ BSA gradient in an airtight sedimentation unit. Cells were allowed to sediment by gravity for $70 \mathrm{~min}$ at $4^{\circ} \mathrm{C}$. Then the gradient was fractionated, and cells in each fraction were staged using a phase contrast microscope. Chosen fractions were pooled to obtain cell populations enriched $(>80 \%)$ in defined pooled stages (spermatocytes, round spermatids, and a mix of round, elongated, and condensed spermatids). Cell pellets obtained after fractionation were disrupted in $8 \mathrm{M}$ urea and quantified by Bradford (Bio-Rad Protein Assay), and Western blots were performed according to standard procedures. Antibodies were used at the following dilutions: H4 S1ph, 1/5000; H3 S10ph (Upstate Biotechnology \#06-570), 1/1000; and TP2 (gift from W.S. Kistler, University of South Carolina, Columbia, SC), $1 / 1000$.

\section{Immunofluorescence on mouse testis}

A fresh testis was frozen in liquid nitrogen and then applied on a Super frost slide. Fixation was performed in $70 \%$ ethanol for 5 min. Slides were dried and stored until use. After a $1 \times$ PBS washing, cells were permeabilized in $0.5 \%$ saponine, $0.25 \%$ Triton, and $1 \times$ PBS for $\sim 15 \mathrm{~min}$ (twice for $7 \mathrm{~min}$ ). Blocking was performed in $5 \%$ milk, $0.2 \%$ Tween, and $1 \times$ PBS for 30 min at room temperature. All the following steps (antibody dilution and washes) were performed using the same buffer (1\% milk, $0.2 \%$ Tween, $1 \times$ PBS). H4 S1 phos and H3 S10 phos antibodies were diluted at $1 / 500$ and $1 / 100$, respectively, and the incubations were overnight at $4^{\circ} \mathrm{C}$. Slides were then washed three times for $5 \mathrm{~min}$, and an anti-rabbit antibody cross-linked with Alexa 488 (Molecular Probes) diluted at 1/500 was applied to the slides for $30 \mathrm{~min}$ at $37^{\circ} \mathrm{C}$. Slides were washed and mounted in Mowiol medium with $250 \mathrm{ng} / \mathrm{mL}$ DAPI. Image acquisitions were made on an Axiophot (Zeiss) microscope using a $-40^{\circ} \mathrm{C}$ chilled CDD camera (Hamamatsu). Images were then processed using Adobe Photoshop.

\section{Acknowledgments}

We thank M. Grunstein, M.A. Osley, R. Strich, and F. Winston for plasmids and yeast strains. We appreciate the help of J. Hayden and F. Keeney at the Wistar Institute Microscope Facility in light microscopy, and D. Bungard for the strain DBY36. We thank J. Rux at the Wistar Institute Bio-informatics Facility for analysis of DAPI measurements, and N.G. Avadhani and L. Devi for use of the Olympus microscope. We appreciate Upstate/Serologicals for their help with the H4 S1ph antibody.
We thank N.C.T. Emre for critical reading of the manuscript, members of the Berger laboratory, N.B.V. Sepuri and G. Moore for valuable discussions. This research was supported by grants from NIH (GM55360) and NSF (MCB-9604208) to S.L.B.; from NIH (GM61986) to M.T.F.; from Lyon Rhône-Alpes Cancéropôle and the Regulome consortium (ANR-05-BLAN-039604) to the S.K. laboratory; and from NIH (GM40922) to C.D.A. X.C. is a Leukemia and Lymphoma Society Special Fellow (LLS3598-06).

\section{References}

Ahn, S.H., Cheung, W.L., Hsu, J.Y., Diaz, R.L., Smith, M.M., and Allis, C.D. 2005a. Sterile 20 kinase phosphorylates histone $\mathrm{H} 2 \mathrm{~B}$ at serine 10 during hydrogen peroxide-induced apoptosis in S. cerevisiae. Cell 120: 25-36.

Ahn, S.H., Henderson, K.A., Keeney, S., and Allis, C.D. 2005b. $\mathrm{H} 2 \mathrm{~B}$ (Ser10) phosphorylation is induced during apoptosis and meiosis in S. cerevisiae. Cell Cycle 4: 780-783.

Barber, C.M., Turner, F.B., Wang, Y., Hagstrom, K., Taverna, S.D., Mollah, S., Ueberheide, B., Meyer, B.J., Hunt, D.F., Cheung, P., et al. 2004. The enhancement of histone H4 and $\mathrm{H} 2 \mathrm{~A}$ serine 1 phosphorylation during mitosis and S-phase is evolutionarily conserved. Chromosoma 112: 360-371.

Bellve, A.R. 1993. Purification, culture, and fractionation of spermatogenic cells. Methods Enzymol. 225: 84-113.

Benjamin, K.R., Zhang, C., Shokat, K.M., and Herskowitz, I. 2003. Control of landmark events in meiosis by the CDK Cdc28 and the meiosis-specific kinase Ime2. Genes \& Dev. 17: 1524-1539.

Briza, P., Breitenbach, M., Ellinger, A., and Segall, J. 1990. Isolation of two developmentally regulated genes involved in spore wall maturation in Saccharomyces cerevisiae. Genes \& Dev. 4: 1775-1789.

Burgess, S.M., Ajimura, M., and Kleckner, N. 1999. GCN5dependent histone $\mathrm{H} 3$ acetylation and RPD3-dependent histone $\mathrm{H} 4$ deacetylation have distinct, opposing effects on IME2 transcription, during meiosis and during vegetative growth, in budding yeast. Proc. Natl. Acad. Sci. 96: 68356840.

Carruthers, L.M. and Hansen, J.C. 2000. The core histone N termini function independently of linker histones during chromatin condensation. J. Biol. Chem. 275: 37285-37290.

Cheung, W.L., Ajiro, K., Samejima, K., Kloc, M., Cheung, P., Mizzen, C.A., Beeser, A., Etkin, L.D., Chernoff, J., Earnshaw, W.C., et al. 2003. Apoptotic phosphorylation of histone H2B is mediated by mammalian sterile twenty kinase. Cell 113: 507-517.

Cheung, W.L., Turner, F.B., Krishnamoorthy, T., Wolner, B., Ahn, S.H., Foley, M., Dorsey, J.A., Peterson, C.L., Berger, S.L., and Allis, C.D. 2005. Phosphorylation of histone H4 serine 1 during DNA damage requires casein kinase II in $S$. cerevisiae. Curr. Biol. 15: 656-660.

Cho, C., Willis, W.D., Goulding, E.H., Jung-Ha, H., Choi, Y.C., Hecht, N.B., and Eddy, E.M. 2001. Haploinsufficiency of protamine-1 or -2 causes infertility in mice. Nat. Genet. 28: $82-86$.

Choy, J.S., Tobe, B.T., Huh, J.H., and Kron, S.J. 2001. Yng2pdependent NuA4 histone $\mathrm{H} 4$ acetylation activity is required for mitotic and meiotic progression. J. Biol. Chem. 276: 43653-43662.

Chu, S. and Herskowitz, I. 1998. Gametogenesis in yeast is regulated by a transcriptional cascade dependent on Ndt80. Mol. Cell 1: 685-696. 
Chu, S., DeRisi, J., Eisen, M., Mulholland, J., Botstein, D., Brown, P.O., and Herskowitz, I. 1998. The transcriptional program of sporulation in budding yeast. Science 282: 699705.

Chua, P. and Roeder, G.S. 1995. Bdf1, a yeast chromosomal protein required for sporulation. Mol. Cell. Biol. 15: 36853696.

Cobb, J., Cargile, B., and Handel, M.A. 1999. Acquisition of competence to condense metaphase I chromosomes during spermatogenesis. Dev. Biol. 205: 49-64.

Deckert, J. and Struhl, K. 2001. Histone acetylation at promoters is differentially affected by specific activators and repressors. Mol. Cell. Biol. 21: 2726-2735.

Dorigo, B., Schalch, T., Bystricky, K., and Richmond, T.J. 2003. Chromatin fiber folding: Requirement for the histone $\mathrm{H} 4$ N-terminal tail. J. Mol. Biol. 327: 85-96.

Friesen, H., Lunz, R., Doyle, S., and Segall, J. 1994. Mutation of the SPS1-encoded protein kinase of Saccharomyces cerevisiae leads to defects in transcription and morphology during spore formation. Genes \& Dev. 8: 2162-2175.

Fuller, M.T. 1993. Spermatogenesis. In The development of Drosophila melanogaster (eds. M. Bate and A. MartinezArias), pp. 71-148. Cold Spring Harbor Laboratory Press, Cold Spring Harbor, NY.

Goto, H., Tomono, Y., Ajiro, K., Kosako, H., Fujita, M., Sakurai, M., Okawa, K., Iwamatsu, A., Okigaki, T., Takahashi, T., et al. 1999. Identification of a novel phosphorylation site on histone H3 coupled with mitotic chromosome condensation. J. Biol. Chem. 274: 25543-25549.

Goto, H., Yasui, Y., Nigg, E.A., and Inagaki, M. 2002. Aurora-B phosphorylates histone $\mathrm{H} 3$ at serine28 with regard to the mitotic chromosome condensation. Genes Cells 7: 11-17.

Govin, J., Caron, C., Lestrat, C., Rousseaux, S., and Khochbin, S. 2004. The role of histones in chromatin remodelling during mammalian spermiogenesis. Eur. J. Biochem. 271: 34593469.

Guacci, V., Hogan, E., and Koshland, D. 1994. Chromosome condensation and sister chromatid pairing in budding yeast. J. Cell Biol. 125: 517-530.

Gurley, L.R., Walters, R.A., and Tobey, R.A. 1973. Histone phosphorylation in late interphase and mitosis. Biochem. Biophys. Res. Commun. 50: 744-750.

Hendzel, M.J., Wei, Y., Mancini, M.A., Van Hooser, A., Ranalli, T., Brinkley, B.R., Bazett-Jones, D.P., and Allis, C.D. 1997. Mitosis-specific phosphorylation of histone H3 initiates primarily within pericentromeric heterochromatin during G2 and spreads in an ordered fashion coincident with mitotic chromosome condensation. Chromosoma 106: 348360.

Henry, K.W., Wyce, A., Lo, W.S., Duggan, L.J., Emre, N.C., Kao, C.F., Pillus, L., Shilatifard, A., Osley, M.A., and Berger, S.L. 2003. Transcriptional activation via sequential histone $\mathrm{H} 2 \mathrm{~B}$ ubiquitylation and deubiquitylation, mediated by SAGAassociated Ubp8. Genes \& Dev. 17: 2648-2663.

Hime, G.R., Brill, J.A., and Fuller, M.T. 1996. Assembly of ring canals in the male germ line from structural components of the contractile ring. J. Cell Sci. 109: 2779-2788.

Hsu, J.Y., Sun, Z.W., Li, X., Reuben, M., Tatchell, K., Bishop, D.K., Grushcow, J.M., Brame, C.J., Caldwell, J.A., Hunt, D.F., et al. 2000. Mitotic phosphorylation of histone $\mathrm{H} 3$ is governed by Ipl1/aurora kinase and Glc7/PP1 phosphatase in budding yeast and nematodes. Cell 102: 279-291.

Hwang, W.W., Venkatasubrahmanyam, S., Ianculescu, A.G., Tong, A., Boone, C., and Madhani, H.D. 2003. A conserved RING finger protein required for histone H2B monoubiquitination and cell size control. Mol. Cell 11: 261-266.
Iwamoto, M.A., Fairclough, S.R., Rudge, S.A., and Engebrecht, J. 2005. Saccharomyces cerevisiae Sps1p regulates trafficking of enzymes required for spore wall synthesis. Eukaryot. Cell 4: $536-544$.

Kimmins, S. and Sassone-Corsi, P. 2005. Chromatin remodelling and epigenetic features of germ cells. Nature 434: 583589.

Klar, A.J. and Halvorson, H.O. 1975. Proteinase activities of Saccharomyces cerevisiae during sporulation. I. Bacteriol. 124: 863-869.

Krisak, L., Strich, R., Winters, R.S., Hall, J.P., Mallory, M.J., Kreitzer, D., Tuan, R.S., and Winter, E. 1994. SMK1, a developmentally regulated MAP kinase, is required for spore wall assembly in Saccharomyces cerevisiae. Genes \& Dev. 8: 2151-2161.

Kupiec, M., Byers, B., Esposito, R.E., and Mitchell, A.P. 1997. Meiosis and sporulation in Saccharomyces cerevisiae. In The molecular and cellular biology of the yeast Saccharomyces (eds. J.R. Pringle et al.), pp. 889-1036. Cold Spring Harbor Laboratory Press, Cold Spring Harbor, NY.

Law, D.T. and Segall, J. 1988. The SPS100 gene of Saccharomyces cerevisiae is activated late in the sporulation process and contributes to spore wall maturation. Mol. Cell. Biol. 8: 912922.

Lewis, J.D., Saperas, N., Song, Y., Zamora, M.J., Chiva, M., and Ausio, J. 2004. Histone H1 and the origin of protamines. Proc. Natl. Acad. Sci. 101: 4148-4152.

Lo, W.S., Trievel, R.C., Rojas, J.R., Duggan, L., Hsu, J.Y., Allis, C.D., Marmorstein, R., and Berger, S.L. 2000. Phosphorlation of serine 10 in histone $\mathrm{H} 3$ is functionally linked in vitro and in vivo to Gen5-mediated acetylation at lysine 14. Mol. Cell. 5: 917-926

Longtine, M.S., McKenzie III, A., Demarini, D.J., Shah, N.G., Wach, A., Brachat, A., Philippsen, P., and Pringle, J.R. 1998. Additional modules for versatile and economical PCR-based gene deletion and modification in Saccharomyces cerevisiae. Yeast 14: 953-961.

Luger, K., Mader, A.W., Richmond, R.K., Sargent, D.F., and Richmond, T.J. 1997. Crystal structure of the nucleosome core particle at $2.8 \AA$ resolution. Nature 389: 251-260.

Lynn, R.R. and Magee, P.T. 1970. Development of the spore wall during ascospore formation in Saccharomyces cerevisiae. J. Cell Biol. 44: 688-692.

Meetei, A.R., Ullas, K.S., Vasupradha, V., and Rao, M.R. 2002. Involvement of protein kinase A in the phosphorylation of spermatidal protein TP2 and its effect on DNA condensation. Biochemistry 41: 185-195.

Meistrich, M.L., Mohapatra, B., Shirley, C.R., and Zhao, M. 2003. Roles of transition nuclear proteins in spermiogenesis. Chromosoma 111: 483-488.

Mitchell, A.P. 1994. Control of meiotic gene expression in Saccharomyces cerevisiae. Microbiol. Rev. 58: 56-70.

Moore, S.C. and Ausio, J. 1997. Major role of the histones H3$\mathrm{H} 4$ in the folding of the chromatin fiber. Biochem. Biophys. Res. Commun. 230: 136-139.

Nislow, C., Ray, E., and Pillus, L. 1997. SET1, a yeast member of the trithorax family, functions in transcriptional silencing and diverse cellular processes. Mol. Biol. Cell 8: 2421-2436.

Nowak, S.J. and Corces, V.G. 2004. Phosphorylation of histone H3: A balancing act between chromosome condensation and transcriptional activation. Trends Genet. 20: 214-220.

Oliva, R. and Dixon, G.H. 1991. Vertebrate protamine genes and the histone-to-protamine replacement reaction. Prog. Nucleic Acid Res. Mol. Biol. 40: 25-94.

Paulson, J.R. and Taylor, S.S. 1982. Phosphorylation of histones 1 and 3 and nonhistone high mobility group 14 by an endog- 
enous kinase in HeLa metaphase chromosomes. I. Biol. Chem. 257: 6064-6072.

Percival-Smith, A. and Segall, J. 1986. Characterization and mutational analysis of a cluster of three genes expressed preferentially during sporulation of Saccharomyces cerevisiae. Mol. Cell. Biol. 6: 2443-2451.

Pivot-Pajot, C., Caron, C., Govin, J., Vion, A., Rousseaux, S., and Khochbin, S. 2003. Acetylation-dependent chromatin reorganization by BRDT, a testis-specific bromodomain-containing protein. Mol. Cell. Biol. 23: 5354-5365.

Polioudaki, H., Markaki, Y., Kourmouli, N., Dialynas, G., Theodoropoulos, P.A., Singh, P.B., and Georgatos, S.D. 2004. Mitotic phosphorylation of histone $\mathrm{H} 3$ at threonine 3. FEBS Lett. 560: 39-44.

Preuss, U., Landsberg, G., and Scheidtmann, K.H. 2003. Novel mitosis-specific phosphorylation of histone H3 at Thr11 mediated by Dlk/ZIP kinase. Nucleic Acids Res. 31: 878-885.

Primig, M., Williams, R.M., Winzeler, E.A., Tevzadze, G.G., Conway, A.R., Hwang, S.Y., Davis, R.W., and Esposito, R.E. 2000. The core meiotic transcriptome in budding yeasts. Nat. Genet. 26: 415-423.

Robzyk, K., Recht, J., and Osley, M.A. 2000. Rad6-dependent ubiquitination of histone H2B in yeast. Science 287: 501504.

Rundlett, S.E., Carmen, A.A., Suka, N., Turner, B.M., and Grunstein, M. 1998. Transcriptional repression by UME6 involves deacetylation of lysine 5 of histone H4 by RPD3. $\mathrm{Na}$ ture 392: 831-835.

Sassone-Corsi, P. 2002. Unique chromatin remodeling and transcriptional regulation in spermatogenesis. Science 296: 2176-2178.

Shogren-Knaak, M., Ishii, H., Sun, J.M., Pazin, M.J., Davie, J.R., and Peterson, C.L. 2006. Histone H4-K16 acetylation controls chromatin structure and protein interactions. Science 311: 844-847.

Sollier, J., Lin, W., Soustelle, C., Suhre, K., Nicolas, A., Geli, V., and de La Roche Saint-Andre, C. 2004. Set1 is required for meiotic S-phase onset, double-strand break formation and middle gene expression. EMBO J. 23: 1957-1967.

Sung, M.T. and Dixon, G.H. 1970. Modification of histones during spermiogenesis in trout: A molecular mechanism for altering histone binding to DNA. Proc. Natl. Acad. Sci. 67: $1616-1623$

Suto, R.K., Clarkson, M.J., Tremethick, D.J., and Luger, K. 2000. Crystal structure of a nucleosome core particle containing the variant histone H2A.Z. Nat. Struct. Biol. 7: 1121-1124.

Utley, R.T., Lacoste, N., Jobin-Robitaille, O., Allard, S., and Cote, J. 2005. Regulation of NuA4 histone acetyltransferase activity in transcription and DNA repair by phosphorylation of histone H4. Mol. Cell. Biol. 25: 8179-8190.

Wei, Y., Yu, L., Bowen, J., Gorovsky, M.A., and Allis, C.D. 1999. Phosphorylation of histone H3 is required for proper chromosome condensation and segregation. Cell 97: 99-109.

Wood, A., Krogan, N.J., Dover, J., Schneider, J., Heidt, J., Boateng, M.A., Dean, K., Golshani, A., Zhang, Y., Greenblatt, J.F., et al. 2003. Bre1, an E3 ubiquitin ligase required for recruitment and substrate selection of Rad6 at a promoter. Mol. Cell 11: 267-274.

Wu, J.Y., Ribar, T.J., Cummings, D.E., Burton, K.A., McKnight, G.S., and Means, A.R. 2000. Spermiogenesis and exchange of basic nuclear proteins are impaired in male germ cells lacking Camk4. Nat. Genet. 25: 448-452.

Yamashita, Y.M., Jones, D.L., and Fuller, M.T. 2003. Orientation of asymmetric stem cell division by the APC tumor suppressor and centrosome. Science 301: 1547-1550.
Yamashita, K., Shinohara, M., and Shinohara, A. 2004. Rad6Brel-mediated histone H2B ubiquitylation modulates the formation of double-strand breaks during meiosis. Proc. Natl. Acad. Sci. 101: 11380-11385.

Yu, Y.E., Zhang, Y., Unni, E., Shirley, C.R., Deng, J.M., Russell, L.D., Weil, M.M., Behringer, R.R., and Meistrich, M.L. 2000. Abnormal spermatogenesis and reduced fertility in transition nuclear protein 1-deficient mice. Proc. Natl. Acad. Sci. 97: 4683-4688.

Zhao, M., Shirley, C.R., Yu, Y.E., Mohapatra, B., Zhang, Y., Unni, E., Deng, J.M., Arango, N.A., Terry, N.H., Weil, M.M., et al. 2001. Targeted disruption of the transition protein 2 gene affects sperm chromatin structure and reduces fertility in mice. Mol. Cell. Biol. 21: 7243-7255.

Zheng, C. and Hayes, J.J. 2003. Structures and interactions of the core histone tail domains. Biopolymers 68: 539-546. 


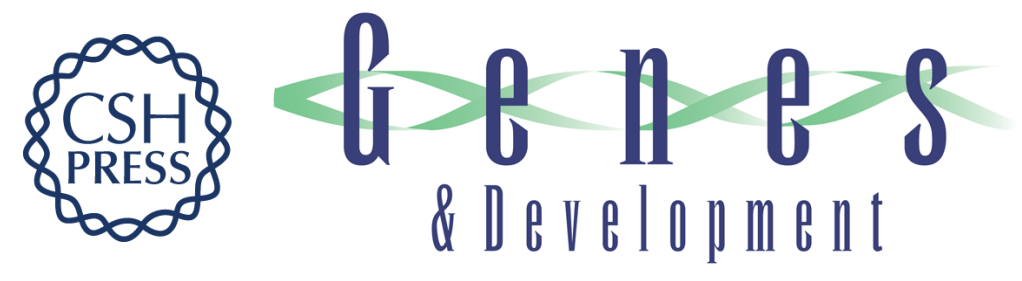

\section{Phosphorylation of histone H4 Ser1 regulates sporulation in yeast and is conserved in fly and mouse spermatogenesis}

Thanuja Krishnamoorthy, Xin Chen, Jerome Govin, et al.

Genes Dev. 2006, 20:

Access the most recent version at doi:10.1101/gad.1457006
Related Content Packing for the germy: the role of histone H4 Ser1 phosphorylation in chromatin compaction and germ cell development
Kristy D. Wendt and Ali Shilatifard
Genes Dev. September , 2006 20: 2487-2491
References This article cites 68 articles, 34 of which can be accessed free at:
http://genesdev.cshlp.org/content/20/18/2580.full.html\#ref-list-1
Articles cited in:
http://genesdev.cshlp.org/content/20/18/2580.full.html\#related-urls

\section{License}
Email Alerting
Receive free email alerts when new articles cite this article - sign up in the box at the top Service

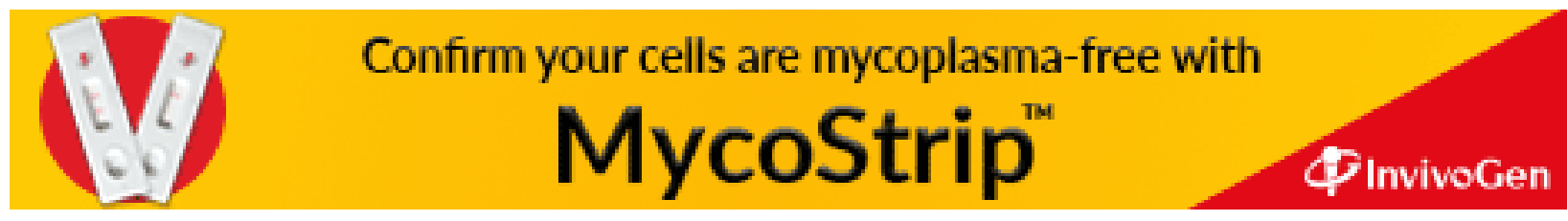

